\title{
A Study to Evaluate the Role of Macro-, Micro-, and Miniesthetics in an Attractive Smile
}

\author{
Roseline Meshramkar ${ }^{1}$, Parkhi Mathur ${ }^{2}$, NB Navya ${ }^{3}$, Mili Gupta ${ }^{4}$, K Lekha ${ }^{5}$
}

\begin{abstract}
Aim: The aim of the study is to evaluate the influence of macro-, micro-, and miniesthetics in an attractive smile.

Materials and methods: The smile photographs of around 214 dental students were taken of age group 18-25 years with natural dentition with specific inclusion and exclusion criteria. Frontal photographs were taken with a Nikon DSLR 200105 mm macro lens ratio 1:1 F/2.8 digital camera. The study was carried out in two stages: stage 1-the photographs were analyzed for beautiful smiles. Those photographs which had a mean score of 60 and above and small standard deviation (3.45) were selected. Out of 214 photographs, 33 photographs were selected for attractive smiles. Stage 2-in the second part of the study different parameters of macro-, micro-, and miniesthetics that influence attractive smile were evaluated. The data obtained were subjected to statistical analysis.

Results: Facial form contributes more in an attractive smile compared with the remaining factors for macroesthetics In factors influencing microesthetics ideally tooth shade plays major role compared with other factors. Crowding ideally plays significant role compared with the remaining factors for miniesthetics.

Conclusion: In restorative dentistry, all factors are to be included during the treatment to enhance the esthetic appearance of the patient thereby improving the smile.

Keywords: Attractive smile, Esthetics, Macroesthetics, Microesthetics, Miniesthetics.

International Journal of Prosthodontics and Restorative Dentistry (2019): 10.5005/jp-journals-10019-1251
\end{abstract}

\section{INTRODUCTION}

Smile is a curve that sets everything straight-Phyllis Diller. Facial attractiveness is defined more by the smile. Smile is a very important positive social behavior for human beings. An attractive smile clearly enhances the acceptance of the individual in our society by improving the initial impression and interpersonal relationship. ${ }^{1}$ It has been found that the eyes and the mouth were the most important factors in a hierarchy of characteristics for determining facial beauty. ${ }^{2}$ Studies have shown that infant's mood and responses to the environment can be influenced by parent's smiles. Also, recent research with functional magnetic resonance imaging technology suggests that adults actually respond neurologically to an attractive and happy face as if it were a reward stimulus. So no wonder, smile is attributed as the universal language. ${ }^{3}$ Esthetics have become increasingly important in the practice of modern dentistry and synonymous with a natural harmonious appearance. ${ }^{1}$

Increasing number of patients are seeking dental treatment for the need of esthetics that is to look attractive. ${ }^{4}$

Esthetic smile requires a perfect integration of facial composition and dental composition. An individual's dentofacial appearance influences social attraction and relationships..$^{5-7}$ Facial composition includes the hard and soft tissues of the face. Dental composition is more specific to teeth and their relationship with gingival tissues. ${ }^{8}$

Attractive faces generally follow the facial third proportionality concept. They tend to have common proportion and relationship that generally differ from normative values. More attractive faces display optimal balance when they present in proportions. ${ }^{7}$

The principles involved in making "pretty smiles" have come to be known within the profession as the discipline of smile design. Smile design theory can be broken down into: facial esthetics, gingival esthetics, macroesthetics, microesthetics, and

\footnotetext{
${ }^{1-5}$ Department of Prosthodontics and Crown and Bridge and Oral Implantology, SDM College of Dental Sciences and Hospital, Sattur, Dharwad, Karnataka, India

Corresponding Author: Mili Gupta, Department of Prosthodontics and Crown and Bridge and Oral Implantology, SDM College of Dental Sciences and Hospital, Sattur, Dharwad, Karnataka, India, Phone: +919945826926, e-mail: guptamili1993@gmail.com

How to cite this article: Meshramkar R, Mathur P, Navya NB, et al. A Study to Evaluate the Role of Macro-, Micro-, and Miniesthetics in an Attractive Smile. Int J Prosthodont Restor Dent 2019;9(4):117-123.

Source of support: Nil

Conflict of interest: None
}

miniesthetics. Macroesthetics involve the elements that make teeth actually look like teeth. The anatomy of natural anterior teeth is specific for each tooth and that tooth's location in the dental arch. It represents the principles that apply when groupings of individual teeth are considered. The relationship between those teeth and the surrounding soft tissue and the patient's facial characteristics creates a dynamic and three-dimensional canvas. ${ }^{9}$ Microesthetics includes fine structures of dental and gingival esthetics. Mini esthetics is the correlation of lips, teeth, and gums at rest and in smile position. It can be appreciated at a visual microesthetic distance of less than 2 feet or within normal make-up distance. ${ }^{10}$

Achieving a successful, healthy, and functional result requires an understanding of the interrelationship among all the supporting oral structures, including muscles, bones, joints, gingival tissues, and occlusion. ${ }^{11}$

The purpose of this study is to evaluate the role of macro-, micro-, and miniesthetics in an attractive smile.

(-) The Author(s). 2019 Open Access This article is distributed under the terms of the Creative Commons Attribution 4.0International License (https://creativecommons. org/licenses/by-nc/4.0/), which permits unrestricted use, distribution, and non-commercial reproduction in any medium, provided you give appropriate credit to the original author(s) and the source, provide a link to the Creative Commons license, and indicate if changes were made. The Creative Commons Public Domain Dedication waiver (http://creativecommons.org/publicdomain/zero/1.0/) applies to the data made available in this article, unless otherwise stated. 


\section{Materials and Methods}

A total of 214 frontal photographs of dental students were taken between the age group of 18-25 years with natural dentition.

\section{Exclusion Criteria}

Students who have

- Undergone orthodontic treatment

- Prosthetic rehabilitation

- Congenitally missing teeth

- Fractured teeth

\section{Data Collec tion}

The approval to use human subjects was obtained from the governing body of Rajiv Gandhi University of Health Sciences, Karnataka. Informed consent of individual subject was obtained. The subjects were induced to a spontaneous maximum open smile (smile displaying teeth). Frontal photograph of middle and lower third of the face was taken with a Nikon DSLR 200105 mm macro lens ratio 1:1 F/2.8 digital camera. Lighting and staging were kept constant for all the photographs. Digital management of the photographs was undertaken using Adobe Photoshop CS (version 8.0, 2003 Adobe) along with visual examination. All photographs were scanned and saved in personal computer using image measurement program (Adobe Photoshop).

The study was carried out in the following two stages:

Stage 1-the photographs were analyzed for beautiful smiles. Those photographs which had a mean score of 60 and above and small standard deviation (3.45) were selected. Out of the 214 photographs, 33 photographs were selected for attractive smiles.

Stage 2-in the second part of the study different parameters of macro- (Table 1), micro- (Table 2), and miniesthetics (Table 3 ) that influence attractive smile were evaluated (Figs 1 to 10).

Table 1: Macroesthetics

\begin{tabular}{|c|c|c|c|}
\hline Parameters & Grade I & Grade II & Grade III \\
\hline $\begin{array}{l}\text { Facial form }{ }^{12,13} \text { a simple way of describ- } \\
\text { ing the face }\end{array}$ & $\begin{array}{l}\text { Mesoprosopic-average or } \\
\text { normal }\end{array}$ & Leptoprosopic-long and narrow & Euryprosopic_-broad and short \\
\hline $\begin{array}{l}\text { Facial proportions }{ }^{11} \\
\text { - Vertical proportion-ideal face is di- } \\
\text { vided sagittally into five equal parts }\end{array}$ & All are equal & Two proportions are equal & All are not equal \\
\hline $\begin{array}{l}\text { Horizontal proportion-a well-pro- } \\
\text { portioned face is divided into three } \\
\text { equal thirds using horizontal planes }\end{array}$ & Width of five eyes & Two to four proportions are equal & All are unequal \\
\hline $\begin{array}{l}\text { Facial and dental midline } e^{9} \text { between the } \\
\text { maxillary centrals should be coinciden- } \\
\text { tal with the facial midline }\end{array}$ & Coinciding & Shifted to right or left & Deviation more than $10 \mathrm{~mm}$ \\
\hline Lip fullness ${ }^{14}$ thickness of the lips & $\begin{array}{l}\text { Mild-some red lip shows } \\
\text { with no lower lip pout }\end{array}$ & $\begin{array}{l}\text { Moderate-moderate red lip } \\
\text { shows with slight lower lip pout }\end{array}$ & $\begin{array}{l}\text { Marked-significant red lip shows } \\
\text { with lower and upper lip pouts }\end{array}$ \\
\hline
\end{tabular}

Table 2: Microesthetics

\begin{tabular}{|c|c|c|c|}
\hline Parameters & Gradel & Grade II & Grade III \\
\hline Gingival height of contour ${ }^{3}$ & $\begin{array}{l}\text { Ideal-gingival margins of maxillary } \\
\text { centrals and canines are at the same } \\
\text { level with lateral } 1.5 \mathrm{~mm} \text { incisal }\end{array}$ & All are at the same level & Cannot be assessed \\
\hline Tooth shade ${ }^{3}$ color of the tooth & Central incisors are brightest & Lateral incisors are brightest & Canines are brightest \\
\hline $\begin{array}{l}\text { Embrassure }{ }^{15} \text { triangular spaces incisal } \\
\text { and gingival to the contact area }\end{array}$ & $\begin{array}{l}\text { Normal-interdental papilla is } \\
\text { between contact point }(\mathrm{CP}) \text { and } \\
\text { interproximal CEJ (IC) }\end{array}$ & $\begin{array}{l}\text { Class } 1 \text {-interdental papilla is } \\
\text { above } \mathrm{CP}\end{array}$ & $\begin{array}{l}\text { Class 2-interdental papilla } \\
\text { is blunt and above IC }\end{array}$ \\
\hline
\end{tabular}

Table 3: Miniesthetics

\begin{tabular}{|c|c|c|c|}
\hline Parameters & Grade I & Grade II & Grade III \\
\hline $\begin{array}{l}\text { Incisal display }{ }^{3} \text { of maxillary incisors during } \\
\text { smile }\end{array}$ & Average $^{16} 75-100 \%$ & Low $<75 \%$ & $\begin{array}{l}\text { High } 100 \% \text { with a band } \\
\text { of gingiva }\end{array}$ \\
\hline $\begin{array}{l}\text { Smile } \operatorname{arc}^{3} \text { relationship of curvature of } \\
\text { incisal edges of maxillary anterior with } \\
\text { curvature of lower lip }\end{array}$ & Parallel_consonant & Straight-flat & Reverse \\
\hline $\begin{array}{l}\text { Smile symmetry }{ }^{11} \text { regularity of } \\
\text { arrangement of forms or objects }\end{array}$ & $\begin{array}{l}\text { Radiation symmetry—from midline to } \\
\text { either side like mirror image }\end{array}$ & $\begin{array}{l}\text { Horizontal symmetry-from } \\
\text { left to right side of smile }\end{array}$ & - \\
\hline $\begin{array}{l}\text { Buccal corridor }{ }^{12} \text { distance between the } \\
\text { maxillary posterior teeth and inside of the } \\
\text { cheek }\end{array}$ & Ideal ${ }^{17}(16 \%)$ & Minimum (8\%) & Maximum (22\%) \\
\hline $\begin{array}{l}\text { Crowding }{ }^{12} \text { discrepancy between tooth and } \\
\text { jaw size }\end{array}$ & No crowding & Mild & Moderate \\
\hline
\end{tabular}




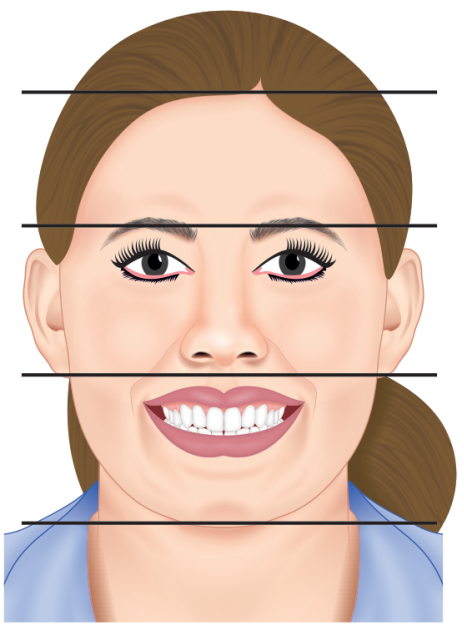

Fig. 1: Vertical facial proportion

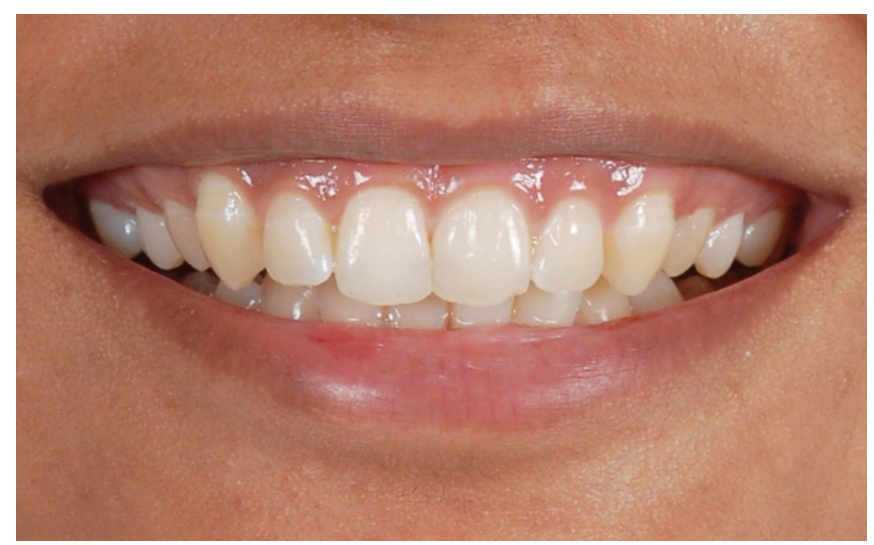

Fig. 3: Mild lip fullness

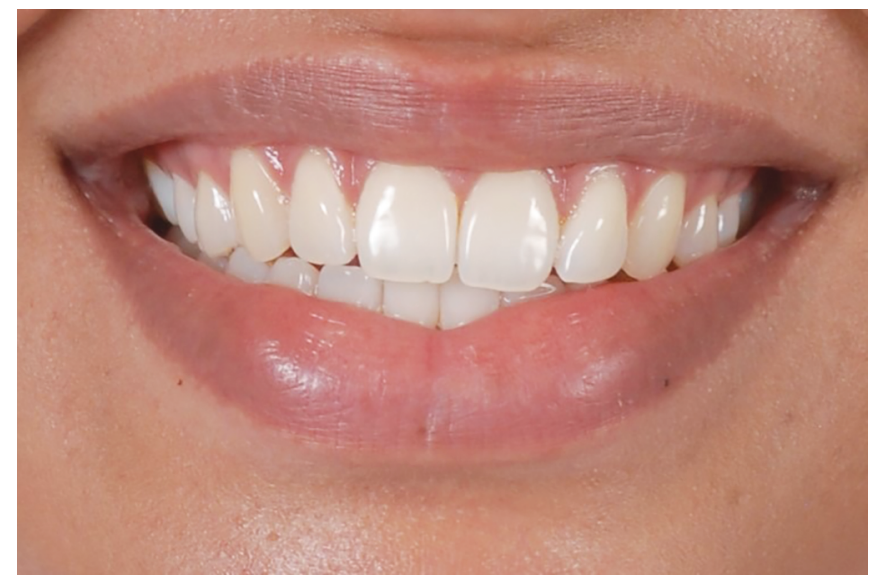

Fig. 5: Marked lip fullness

Certain scoring criteria were followed to analyze attractive smile as follows:

Grade I—ideal/normal, grade II—average, and grade III-below average.

\section{Results}

Out of the 214 frontal photographs, 33 were selected for attractive smile.

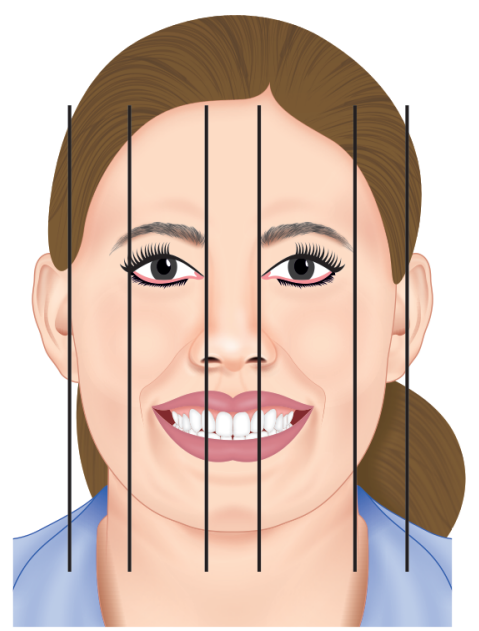

Fig. 2: Horizontal facial proportion

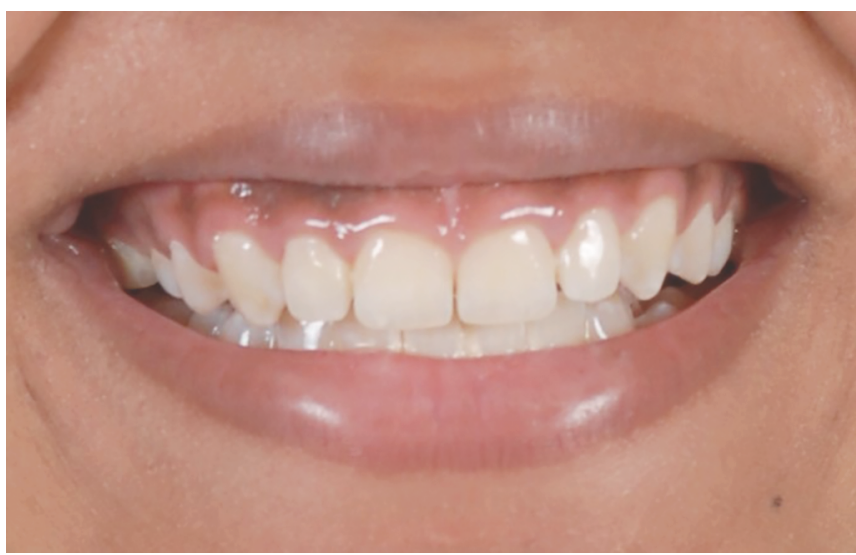

Fig. 4: Moderate lip fullness

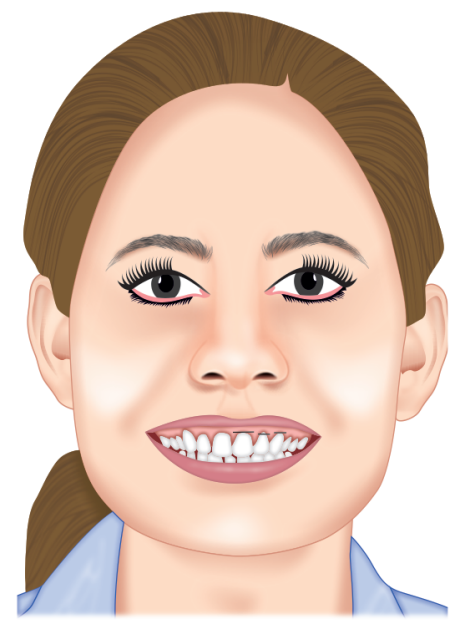

Fig. 6: Ideal gingival height of contour

Ideal factors influencing macroesthetics are presented in Figure 11: $69.6 \%$ had ideal facial form, $54.5 \%$ had ideal facial and dental midline, $39.3 \%$ had ideal vertical proportion, $27.2 \%$ had ideal lip fullness, and $24.2 \%$ had ideal horizontal proportion.

Average factors influencing macroesthetics are presented in Figure $12: 75.7 \%$ had average horizontal proportion, $51.5 \%$ had 


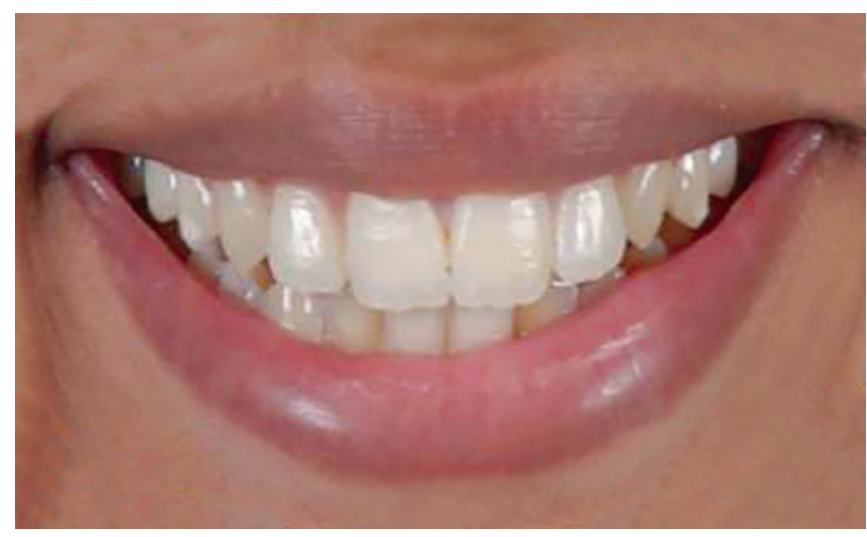

Fig. 7: Average incisal display

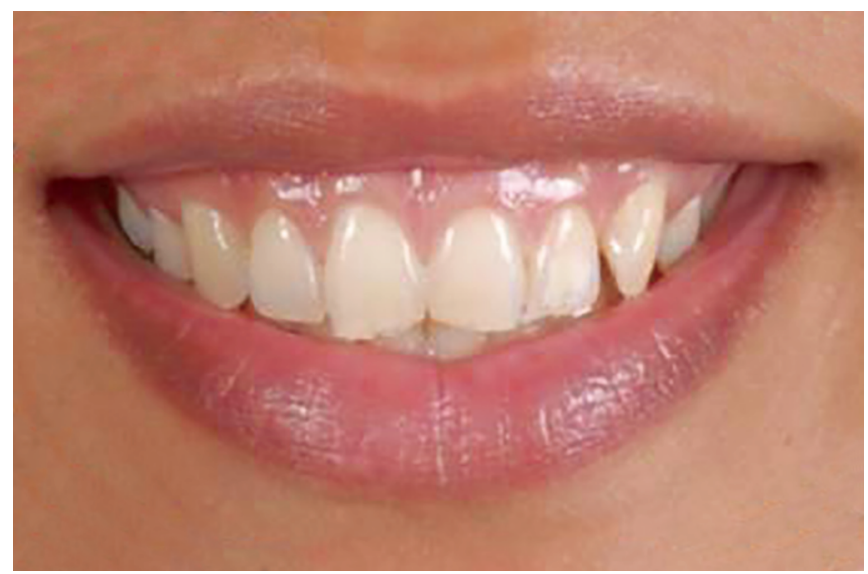

Fig. 9: High incisal display

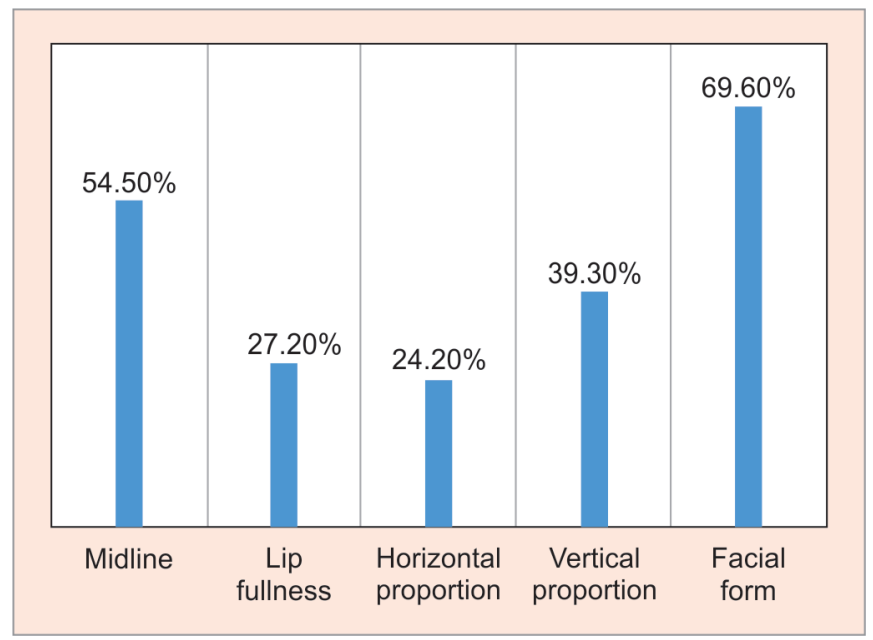

Fig. 11: Ideal factors influencing macroesthetics

average vertical proportion, $45.4 \%$ had average facial and dental midline, $45.4 \%$ had average lip fullness, and $24.2 \%$ had average facial form.

Below average factors influencing macroesthetics are presented in Figure 13: 27.2\% had below average lip fullness, 9\% had below average vertical proportion, $6 \%$ had below average facial form, $0 \%$ had below average horizontal proportion, and $0 \%$ had below average facial and dental midline.

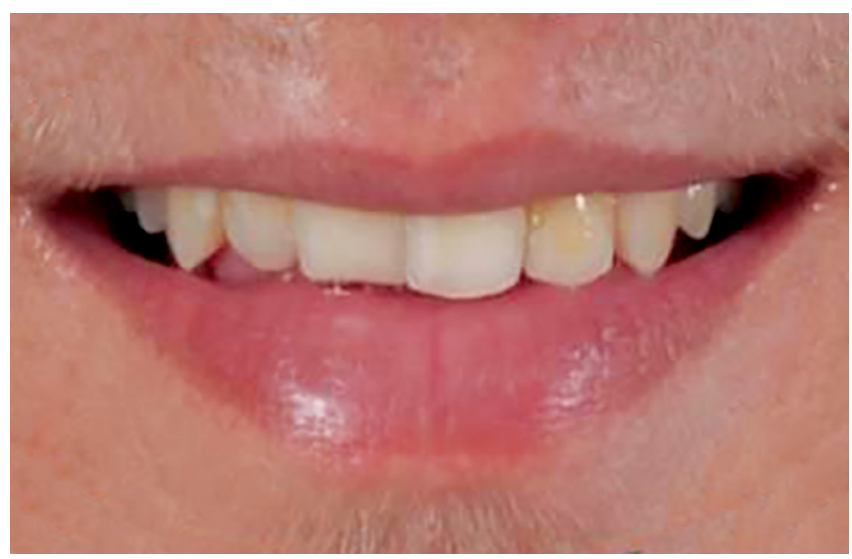

Fig. 8: Low incisal display

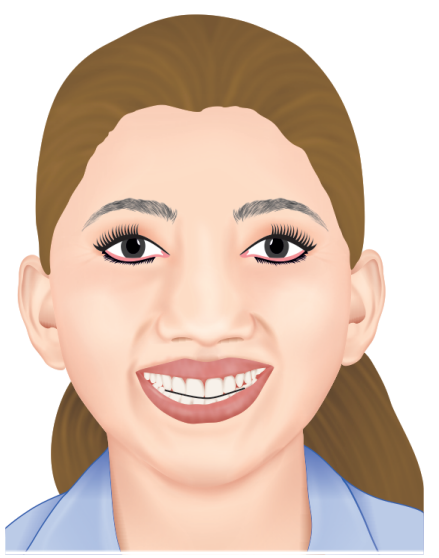

Fig. 10: Parallel smile arc/smile curve

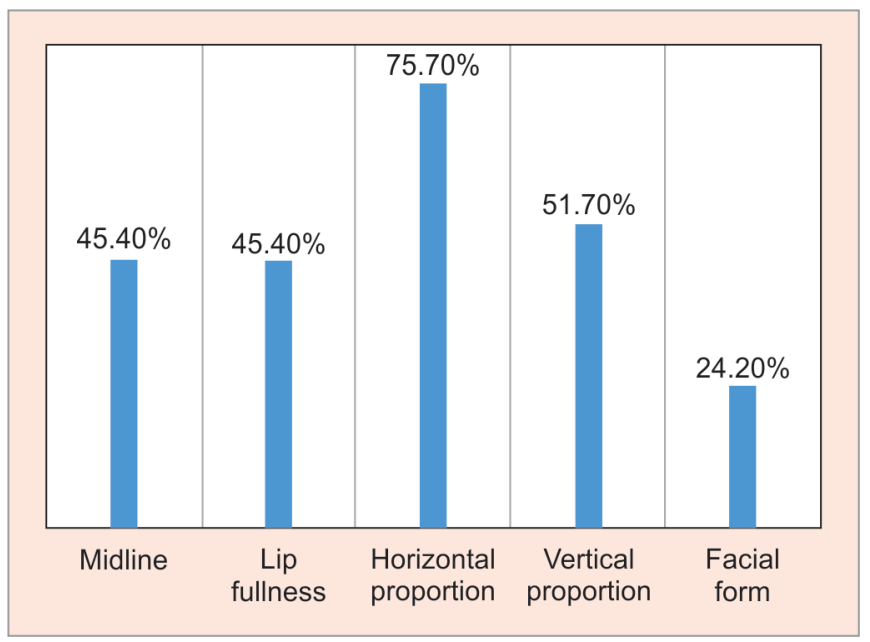

Fig. 12: Average factors influencing macroesthetics

Ideal factors influencing microesthetics are presented in Figure 14: $93.9 \%$ had ideal tooth shade, $42.4 \%$ had ideal gingival height of contour, and $3 \%$ had ideal embrasures.

Average factors influencing microesthetics are presented in Figure 15: $96 \%$ had average embrasures, $6 \%$ had average tooth shade, and $0 \%$ had average gingival height of contour.

Below average factors influencing microesthetics are presented in Figure 16: 57.7\% had below average gingival height of contour, 


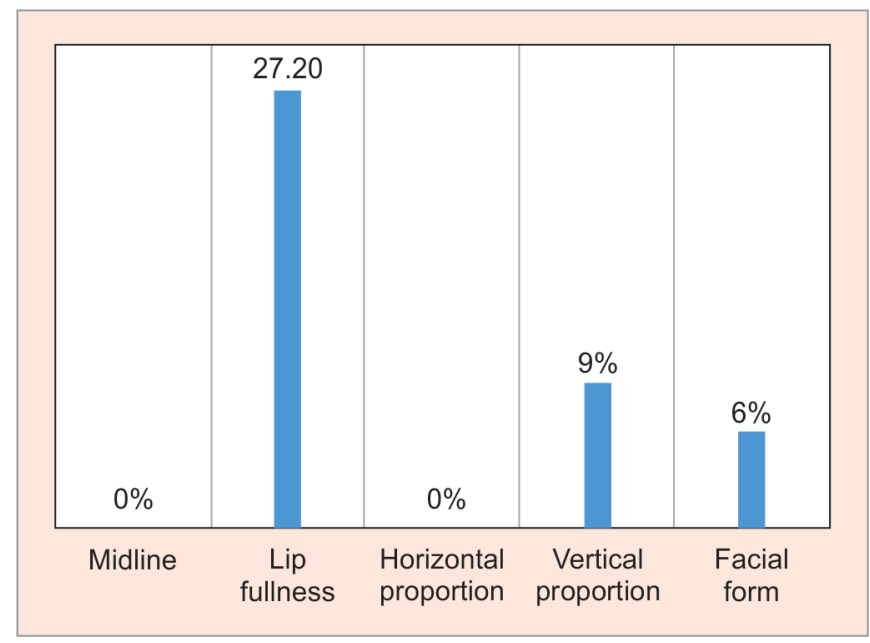

Fig. 13: Below average factors influencing macroesthetics

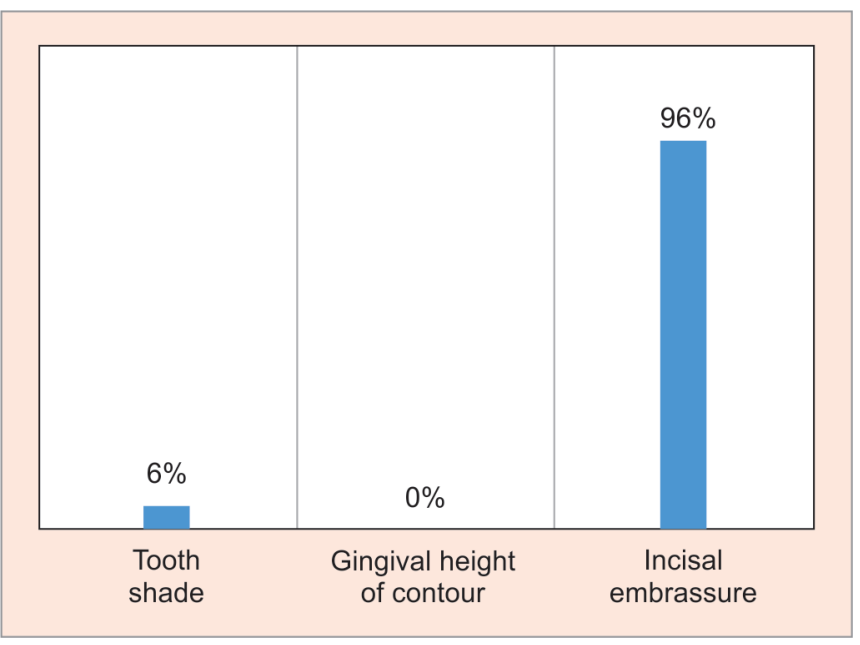

Fig. 15: Average factors influencing microesthetics

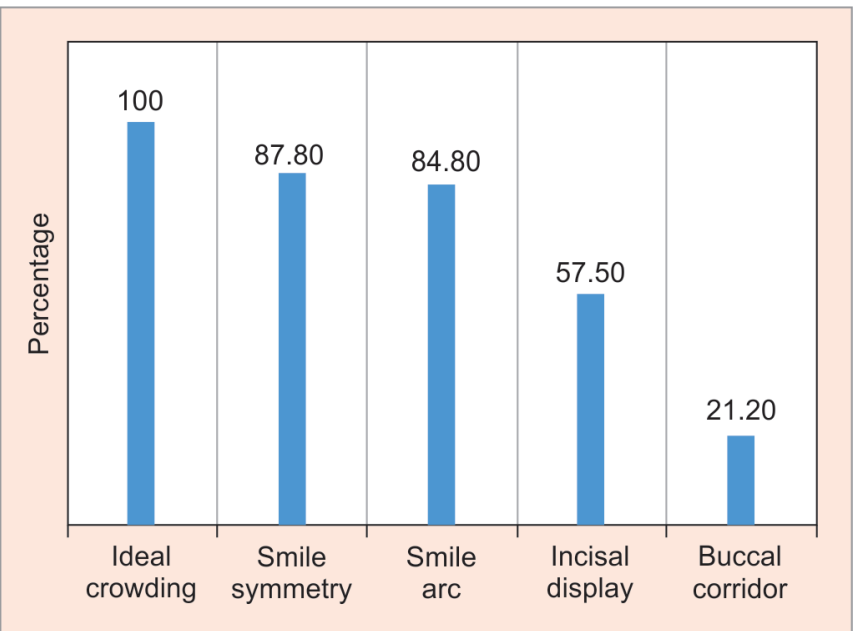

Fig. 17: Ideal factors influencing miniesthetics

$0 \%$ had below average tooth shade, and $0 \%$ had below average embrasures.

Ideal factors influencing miniesthetics are presented in Figure 17: $100 \%$ had ideal crowding, $87.8 \%$ had ideal smile

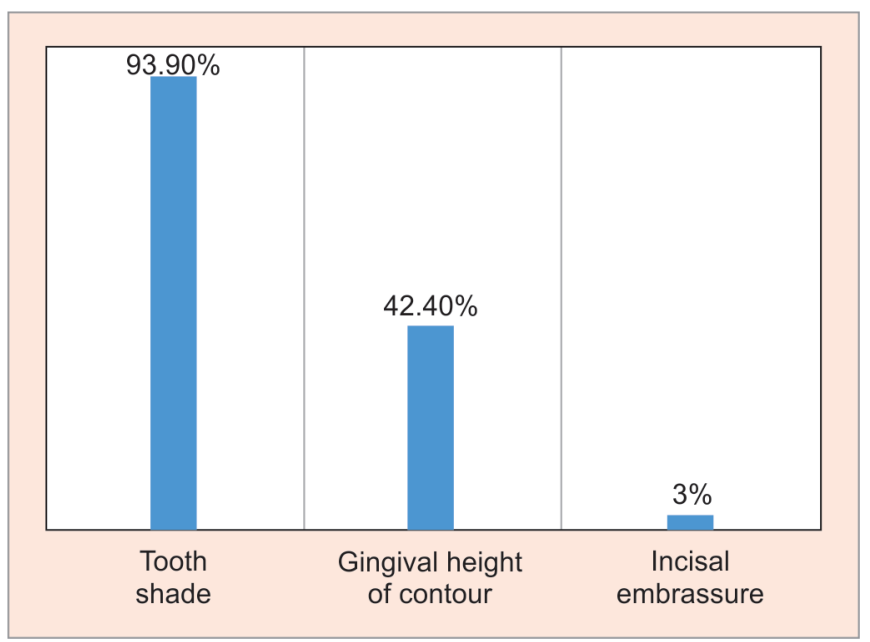

Fig. 14: Ideal factors influencing microesthetics

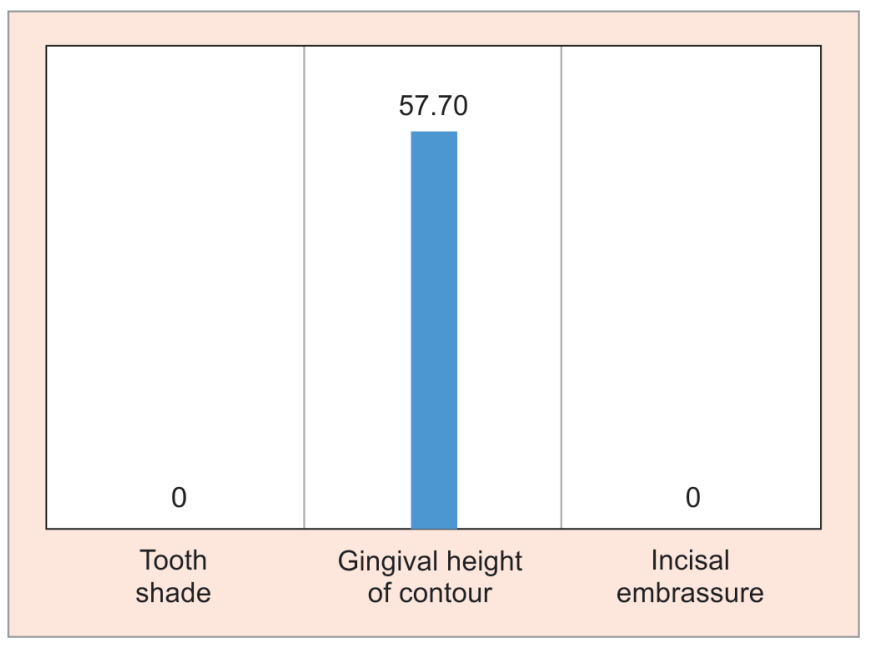

Fig. 16: Below average factors influencing microesthetics

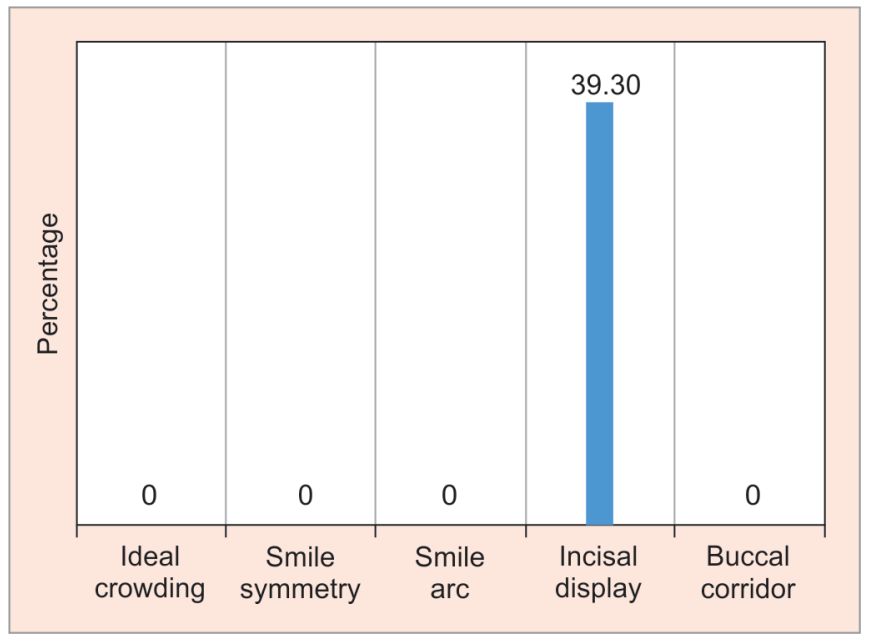

Fig. 18: Average factors influencing miniesthetics

symmetry, $84.8 \%$ had ideal smile arc, $57.5 \%$ had ideal incisal display, and $21.2 \%$ had ideal buccal corridors.

Average factors influencing miniesthetics are presented in Figure 18: $78.7 \%$ had average buccal corridors, $15.1 \%$ had average 


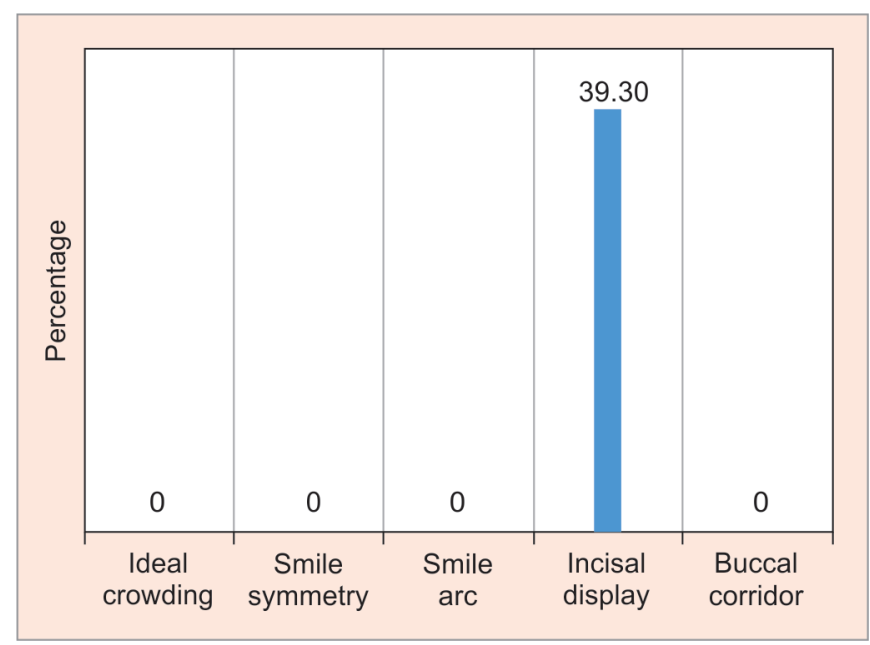

Fig. 19: Below average influencing miniesthetics

smile arc, $12.1 \%$ had average smile symmetry, $3 \%$ had average incisal display, and $0 \%$ had average crowding.

Below average influencing miniesthetics are presented in Figure 19: $39.3 \%$ had below average incisal average, $0 \%$ had below average smile arc, $0 \%$ had below average smile symmetry, $0 \%$ had below average buccal corridors, and $0 \%$ had below average crowding.

\section{Discussion}

Esthetic dentistry can only be achieved if dentists understand the form, texture, and color of natural teeth and how the teeth relate to other facial structure. Basic knowledge of the esthetic aspects of natural dentition may contribute in a simple, yet efficient manner toward reducing difficulties in dentist vs patient relationship with regard to the patient's smile and esthetic appearance and psychosocial integration. ${ }^{4}$

In 1996, Mack stated that the lower $1 / 3$ rd of face significantly influences facial appearance. In this study, it was found that $51.5 \%$ of the students had got average score of vertical proportion, i.e., two of the proportions are equal which was more influencing and it contradicts with Mack's statement. ${ }^{18}$ According to Server's study done in 1993, the face is divided sagittally into five equal parts from helix of one ear to the other ear. Width of face is equal to width of five eyes. We found that $75.7 \%$ of the students had got an average score of horizontal proportion, i.e., any $2-4$ proportions are equal which does not show correlation with Server's study. ${ }^{19}$ In this study, we observed that $54.5 \%$ of the students had got an ideal score for facial and dental midline, which corresponds with the study conducted by Frush and Fisher in 1958, who found that to attain optimal esthetics, facial and dental midline must coincide with maxillary and mandibular central incisor midline. ${ }^{20}$ In 2015, Werschler et al. followed the Allergen lip fullness scale and stated that thin lips are not ideal for a smile. In this study, $45.4 \%$ of the students had moderate lip fullness which relates to Werschler et al.'s study. ${ }^{14}$ Seixas et al. in 2012 stated that gingival contours must coincide with cementoenamel junction (CEJ), i.e., central incisors and canines are at the same level but apical to margins of lateral incisors. In this study, $57.5 \%$ of student's gingival height of contour could not be assessed. ${ }^{21}$ In 2006, Naini et al. stated that tooth shade changes from midline posteriorly, i.e., central incisors and premolars are the brightest than lateral incisors with canines being the least bright. We found that $93.9 \%$ of the students had got ideal score for tooth shade which is in accordance with Naini et al.'s study. ${ }^{22}$ Gingival embrasures are triangular spaces which are incisal and gingival to the contact area which are also called as black triangles. In 2005, Sabri stated that short interdental papillae leave an open gingival embrasure above the contact point which gives unesthetic appearance. This study shows that $96.6 \%$ of the students had gingival embrasures above interdental contact point which contradicts Sabri's study. However, in adults they arise due to the loss of gingival tissue but when crowded and rotated maxillary incisors are corrected orthodontically, contact area moves incisally and black triangles may appear. ${ }^{23}$ Zachrisson in 1998 found that average smile, i.e., $75-100 \%$ of upper incisor display gives a more youthful look which matches with this study showing $57.5 \%$ of the students having an ideal score of incisal display. ${ }^{24}$ In 1997, Goldstein's study found that relationship of curvature of incisal edges of maxillary anteriors with curvature of lower lip should be parallel. In this study, $84.8 \%$ of sample size had parallel or consonant smile arc which is in accordance with Goldstein's study. ${ }^{25}$ Symmetry is the harmonious arrangement of several elements with respect to each other. Symmetrical length and width are more crucial for the centrals. It becomes less absolute as we move further away from the midline. Balance is observed as the eyes move distally from the midline, so that both the right and left sides of the smile are well balanced. About $87.8 \%$ of the students had got ideal score of smile symmetry, i.e., radiation symmetry (like a mirror image) which is in agreement with the article by Bhuvaneswaran in 2010. ${ }^{11}$ In 1970, Husley ${ }^{26}$ demonstrated that there is no relationship between buccal corridor and esthetics. But we observed that buccal corridor influences esthetics which does not link with Husley's study. Morgolis (1997), ${ }^{27}$ Dong et al., and Morley stated that smile with more posterior teeth visibility is more pleasant than less posterior teeth and more buccal corridor visibility. In this study, $78.7 \%$ of the students had got average score for buccal corridor which synchronizes with Morgolis, Dong et al., and Morley's study., 28,29 In 2016, Heravi et al. concluded that dental attractiveness can be predicted by upper anterior crowding. In this study, $100 \%$ of the students had got ideal score, i.e., no crowding is highly esthetic which concurs with Heravi's study. ${ }^{30}$

Factors influencing macro-, micro-, and miniesthetics in a large sample can be evaluated in both attractive and nonattractive smiles. The cumulative visual impact of the smile cannot be associated exclusively with the beauty of individual teeth. Therefore, the smile analysis must be assessed in association with the face to define esthetic rehabilitation of the smile. ${ }^{1}$

An attractive smile usually shows symmetry and proportion among teeth, gingiva, and lips. Amendment of dental esthetic inconsistencies desires cautious evaluation, planning, and multidisciplinary approach. ${ }^{31}$ Thus, parameters of macroesthetics of natural dentition combined with micro- and miniesthetics influence attractive smile. ${ }^{9}$

\section{Conclusion}

Within the limitations of the study it was concluded that:

- In factors influencing macroesthetics, ideally facial form contributes more in an attractive smile compared with the remaining factors.

- In factors influencing microesthetics ideally tooth shade plays major role compared with other factors.

- In factors influencing miniesthetics ideally crowding plays significant role compared with the remaining factors. 


\section{REFERENCES}

1. Dent EJ.A study to evaluate the prevalence of golden proportion and RED proportion in aesthetically pleasing smiles. Eur J Prosthodont Rest Dent 2013;21(1):29-33.

2. BatwaW.Theinfluence of the smile on the perceivedfacial typeesthetics. Biomed Res Int 2018;2018:3562916. DOI: 10.1155/2018/3562916.

3. Bansal A, Jain A, Patel S, et al. Mini and micro esthetics in orthodontics: review on clinical considerations in orthodontic diagnosis. Arch Dent Med Res 2015;1(1):32-39.

4. Renner RP. Dental esthetics. In: Renner RP, ed. An introduction to dental anatomy and esthetics. Chicago: Quintessence; 1985. pp. 241-276.

5. Burstone CJ. The intergumental profile. Am J Orthod 1958;44:1-25. DOI: 10.1016/S0002-9416(58)90178-7.

6. Peck S, Peck L. Selected aspects of the art and science of facial esthetics. Semin Orthod 1995;1(2):105-126. DOI: 10.1016/S10738746(95)80097-2.

7. Shaw WC, Rees G, Dawe M, et al. The influence of dentofacial appearance on the social attractiveness of young adults. Am J Orthod 1985;87(1):21-26. DOI: 10.1016/0002-9416(85)90170-8.

8. Kokich Jr VO, AsumanKiyak H, Shapiro PA. Comparing the perception of dentists and lay people to altered dental esthetics. J Esthet Dent 1999;11(6):311-324. DOI: 10.1111/j.1708-8240.1999.tb00414.x.

9. Morley J, Eubank J. Macroesthetic elements of smile design. J Am Dent Assoc 2001;132(1):39-45. DOI: 10.14219/jada.archive. 2001.0023.

10. Koirala S. Smile Design Wheel ${ }^{\mathrm{TM}}$ : a practical approach to smile design. Cosmetic Dentistry 2019;3:24-28.

11. Bhuvaneswaran M. Principles of smile design. J Conserv Dent 2010;13(4):225-232. DOI: 10.4103/0972-0707.73387.

12. Fishman LS. Individualized evaluation of facial form. Am J Orthod Dentofacial Orthop 1997;111(5):510-517. DOI: 10.1016/s0889-5406(97) 70288-9

13. Franco FC, Araujo TM, Vogel CJ, et al. Brachycephalic, dolichocephalic and mesocephalic: is it appropriate to describe the face using skull patterns. Dent Press J Orthod 2013;18(3):159-163. DOI: 10.1590/s217694512013000300025

14. Werschler WP, Fagien S, Thomas J, et al. Development and validation of a photographic scale for assessment of lip fullness. Aesthet Surg J 2015;35(3):294-307. DOI: 10.1093/asj/sju025.

15. Ravishankar Y, Srinivas K, Sharma SK, et al. Management of black triangles and gingival recession: a prosthetic approach. Indian J Dent Sci 2012;4(1):141-145.
16. Tjan AH, Miller GD, The JG. Some esthetic factors in a smile. J Prosthet Dent 1984;51(1):24-28. DOI: 10.1016/s0022-3913(84) 80097-9.

17. Shalini GN, Chandulal J, Charitha GN, et al. Buccal corridor and it's effects on smile esthetics in Hyderabad population-an in vitro study. Int J Recent Sci Res 2017;8(5):16923-16928. DOI: 10.24327/ ijrsr.2017.0805.0246.

18. Mack MR. Perspective of facial esthetics in dental treatment planning J Prosth Dent 1996;75(2):169-176. DOI: 10.1016/s0022-3913(96) 90095-5.

19. Sarver DM. The esthetic impact of orthodontics: planning treatment to meet patients' needs. J Am Dent Assoc 1939;124(11):99-102. DOI: 10.14219/jada.archive.1993.0234.

20. Frush JP, Fisher RD. The dynesthetic interpretation of the dentogenic concept. J Prosthet Dent 1958;8(4):558-581. DOI: 10.1016/00223913(58)90043-X.

21. Seixas MR, Costa-Pinto RA, Araújo TM. Gingival esthetics: an orthodontic and periodontal approach. Dent Press J Orthod 2012;17(5):190-201.

22. Naini FB, Moss JP, Gill DS. The enigma of facial beauty: esthetics, proportions, deformity, and controversy. Am J Orthod Dentofacial Orthop 2006;130(3):277-282. DOI: 10.1016/j.ajodo.2005. 09.027.

23. Sabri R. The eight components of a balanced smile. J Clin Orthod 2005;39(3):155-167.

24. Zachrisson BU. Esthetic factors involved in anterior tooth display and the smile: vertical dimension. J Clin Orthod 1998;32:432-445.

25. Goldstein RE. Esthetics in dentistry. PMPH-USA; 2014.

26. Hulsey $C M$. An esthetic evaluation of lip-teeth relationships present in the smile. Am J Orthod 1970;57:132-144.

27. Margolis MJ. Esthetic considerations in ortho-dontic treatment of adults. Dent Clin North Am 1997;41:29-48.

28. Ritter DE, Gandini Jr LG, Pinto Ados S, et al. Analysis of the smile photograph. World J Orthod 2006;7(3):279-285.

29. Dong JK, Jin TH, Cho HW, et al. The esthetics of the smile: a review of some recent studies. Int J Prosthodont 1999;12(1):9-19.

30. Heravi F, Ahrari F, Rashed R, et al. Evaluation of factors affecting dental esthetics in patients seeking orthodontic treatment. Int J Orthod Rehabil 2016;7(3):79-84. DOI: 10.4103/2349-5243.192526.

31. Kohli S, Yee A. Smile enhancement with anatomic diagnostic wax-up and comprehensive esthetic smile designing. J Int Oral Health 2019;11(4):221-227. DOI: 10.4103/jioh.jioh_191_17. 